\title{
A PUSH AND PULL INTERVENTION TO CONTROL AVIAN INFLUENZA: A LESSON LEARNED FROM THE WESTERN JAVA POULTRY SECTOR
}

\author{
Dikky Indrawan*), Arjan Stegeman**), Arief Daryanto*), and Henk Hogeveen ${ }^{* * *}$ \\ *) School of Business, IPB University \\ Jl Raya Pajajaran Kampus IPB Baranangsiang, Bogor 16129, Indonesia \\ **) Department of Farm Animal Health-Epidemiology, Infectiology and Health, Utrecht University The Netherlands \\ 3584 CS Utrecht, The Netherlands \\ $\left.{ }^{* * *}\right)$ Business Economics, Department of Social Sciences, Wageningen UR, The Netherlands \\ Droevendaalsesteeg 4, 6708 PB Wageningen, The Netherlands
}

\begin{abstract}
HPAI H5N1 is considered endemic in Indonesian poultry and poses a major challenge to animal and human health authorities. The complex structure of the Indonesian poultry meat value chain is an important reason for the limited efficacy of HPAI control in Indonesia so far. The paper objective is to describe how to implement a push-and-pull strategy in the poultry supply chain to control HPAI infection in Western Java. More specifically, this study investigates the poultry value chain in Western Java in relation to consumers' behavior and governance of the value chain. Implementation of biosecurity and HPAI control measures was strongly related to the governance structure of the chain, with interactions that accentuating the risk of HPAI. In conclusion, a push strategy, as an incentive mechanism, should be designed in such a way that it pays attention to the interactions between actors in a value chain and their impact on introduction and transmission of disease. Moreover, a pull strategy as an incentive mechanism for consumers forcing producers to improve their production environment into higher levels of biosecurity is expected to be less effective than a push strategy targeting producers.
\end{abstract}

Keywords: avian influenza, biosecurity, consumer preferences, willingness to pay, a push and pull strategy

\begin{abstract}
Abstrak: HPAI H5N1 saat ini sudah menjadi endemik pada komoditas unggas Indonesia dan memberikan tantangan yang besar terhadap otoritas kesehatan hewan dan manusia. Hingga saat ini, kompleksitas struktur rantai nilai pada daging unggas di Indonesia menjadi alasan penting yang membatasi kesuksesan pengendalian HPAI di Indonesia. Tujuan makalah ini adalah untuk menggambarkan bagaimana upaya untuk menerapkan strategi push-and-pull di dalam rantai pasokan unggas yang bertujuan untuk mengendalikan infeksi HPAI di Jawa Barat. Lebih khusus lagi, penelitian ini meneliti rantai nilai unggas di Jawa Barat terkait dengan perilaku konsumen dan tata kelola rantai nilai. Implementasi biosecurity dan langkah-langkah pengendalian HPAI sangat terkait dengan interaksi yang berisiko HPAI pada berbagai tata kelola di dalam struktur rantai nilai. Sebagai kesimpulan, strategi push yang digunakan sebagai mekanisme insentif harus dirancang dengan memperhatikan interaksi antara aktor dalam rantai nilai dan dampaknya terhadap introduksi dan penularan penyakit. Selain itu, strategi pull, sebagai mekanisme yang memberikan insentif bagi konsumen untuk memaksa produsen untuk meningkatkan biosekuriti yang lebih tinggi pada produksinya, ternyata kurang efektif daripada strategi push yang menargetkan produsen.
\end{abstract}

Kata kunci: avian influenza, biosecurity, preferensi konsumen, WTP, strategi push and pull

\footnotetext{
${ }^{1}$ Corresponding author:

Email: rdikky@apps.ipb.ac.id
} 


\section{INTRODUCTION}

Since the first outbreak of highly pathogenic avian influenza (HPAI) H5N1 in Indonesia, government efforts to control the outbreak followed the general approach used in other countries as advised by FAO. The Indonesian government faced difficulties for a variety of reasons (Pramuwidyatama et al. 2018). One of the main reasons is the complex structure of the poultry supply chain (FAO, 2011). The structure of the poultry chain has an effect on the chain actors' participation in HPAI control. The poultry supply chain structure can be defined as the combination of links and interactions between actors involved in the production of poultry meat. A proper understanding of this structure will provide a clear overview for animal disease control, based on the interaction in the livestock production and marketing channels (Rich et al. 2011). This includes the response of different stakeholders to disease outbreak, which is related to how they interact with different control measures (Rich and Perry, 2011). Therefore, without proper knowledge on the structure, the efficacy of proposed control strategies to manage HPAI H5N1 may be lower than expected. One possible reason why the efforts of the Indonesian government were not always successful may have been caused by the lack of clarity in defining and targeting the most important actors in the control of HPAI. Moreover, the control measures may not have been aimed at the proper stage of the production cycle or may not have addressed the interaction between different actors.

A proper understanding of the structure of a value chain in relation to the control of a contagious disease can be gained by linking a value chain analysis with a veterinary epidemiology and with the insight of poultry consumers (Indrawan et al. 2018a). The knowledge generated in such an approach can be contextualized in the structure related to the chain governance. It can provide important input for the development of government strategies for the control of HPAI. In this way, efforts to control HPAI will better match the structure of the poultry value chain and will be more effective.

In order to gain knowledge about the relationship between the value chain structure and control of HPAI, in this research, first, we have provided a better description of the Western Java value chain in relation to introduction and transmission of HPAI. Second we studied the application of biosecurity practices at the farm level (the micro governance level), especially in relation to farm business types. Third, we investigated the consumers' behavior in relation to the market structure and their impact on HPAI control. Together, those aspects provide the opportunity to give a broad evaluation in which direction HPAI control should be planned to be effective. In this respect, HPAI control may be directed towards pushing biosecurity practices (a push strategy) or pulling the production by changing consumers' demand (a pull strategy) or a combination of both approaches.

\section{METHODS}

The main scientific contribution of this paper is to link institutional economics with veterinary epidemiology. Highly contagious animal diseases, such as HPAI, do have a huge impact on farm incomes, food security and a country's economy. In many countries, with more complex governance structures, highly contagious animal diseases are endemic. Although socio-economic work on the control of contagious diseases has been carried out (e.g., Dijkhuizen et al. (1995) and King et al. (2007)), it was mostly done in Western countries and aimed at cost minimization, assuming the measures to be feasible. Because of the low level of compliance, such an approach is not useful in countries such as Indonesia. Measures should be evaluated for their efficacy, both in terms of epidemiology and in terms of adoption by actors in the value chain. Combining a value chain analysis with epidemiological knowledge was novel. The use of a value chain map combined with an in-depth assessment of governance structures through different typologies of transactional dynamics and transaction cost economics, a quantitative estimate of market power, and the probability of HPAI introduction and transmission can be added to the knowledge base on the interactions in the poultry structure. This approach differs considerably from previous HPAI studies based on poultry value chain (Idris et al. 2015, Loth et al. 2011, Sudarman et al. 2010, Sumiarto and Arifin, 2008, Willyanto et al. 2010).

Using this novel approach, we obtained a detailed understanding of the structure of the poultry sector and were able to untangle the complexity of control of HPAI in Western Java. In our analysis, we used the value chain as a basis for risk assessment of the probability of an unwanted event and its ensuing consequences (Costard et al. 2014). The probability of 
HPAI introduction and transmission was addressed in relation with the relative importance of the different actors in the poultry value chains. Therefore, our work combines a farm level (micro-governance) assessment for biosecurity practices, complemented with novel knowledge of the incentive mechanisms that play a role in the prevention of animal diseases in the poultry value chain (Barnes et al. 2015, Basuno et al. 2010, Gerdoçi et al. 2018, Gramig and Horan, 2011, Wacker et al. 2016). In order to combine the value chain information with epidemiological information, we used a qualitative assessment to measure risk in the context of HPAI. This assessment method was adapted from similar studies by the European Food Safety Authority (2006) and Kasemsuwan et al. (2009).

The paper made use of a wide range of methodological approaches for collecting data (Table 1). We mapped the poultry value chains and assessed governance, economic performance of actors and epidemiological relationships between actors in workshops, site visits and in-depth interviews. These qualitative approaches were used, partly to overcome our limited sampling frame and resources, given the complexity of value chains. On the other hand, qualitative approaches, when carried out in a systematic manner, may yield a much better understanding of the structure of the value chain, especially in an exploratory phase. For instance, in order to fully quantify the epidemiological relations between actors in the value chain, many years of data collection and a huge number of samples taken during HPAI outbreaks would be required. For example, in the quantitative research of Indriani et al. (2010), 83 live birds markets were sampled to establish the risk of avian influenza transmission from poultry to humans. The relatively small number of 26 semi-structured interviews with key informants did reveal a good overview of the risks for transmission and introduction. As a result, this study provides information on the most important epidemiological pathways in the poultry value chain and can be used to start quantitative epidemiological research in those pathways. Surveys in four important poultry production regions (Ciamis, Tasikmalaya, Subang and Sukabumi) were conducted to collect data on existing biosecurity measures. In order to obtain a good overview, we chose a stratified data collection approach. Besides questionnaires, on-farm measurements provided insight in available biosecurity measures. Surveys were also conducted to collect information on consumers. We also used the non-probability sampling method, also known as quota sampling, to select respondents. The sample was split based on market channels, to determine where the respondents mainly shop for poultry meat. This method assures that smaller groups (in this case the modern channel) are adequately represented in the sample. The consumer study aimed at evaluating consumers' behavior after HPAI outbreaks used Spiggle and Sewall's (1987) and Heider and Moeller's (2012) research framework for consumers' choice of market channel. Moreover, the study added an additional factor to that framework, i.e. the consumers' perceived risk in the situation of food unsafety (Yeung and Morris (2001). A discrete choice experiment was used to explain the Western Java consumers' preferences for selected poultry meat attributes and their willingness to pay (WTP) for those attributes. The choice experiment in this study was based on Lancaster's consumer theory (Lancaster, 1966) was used to design the choice experiment combined with the random utility theory (McFadden, 2001).

We used a randomized choice-based conjoint research design. Methods, and respondents for each perspective, and research objective of the study in Table 1. Although intrinsically not a methodology, this paper did take a novel approach to socio-economic research supporting decisions on disease control. It combined studies supporting decisions for a push strategy as well as studies supporting decisions for a pull strategy. Doing so, we can evaluate the direction of governmental interventions in a holistic way, being able to combine both push and pull approach studies. This approach enabled us to provide knowledge and recommendations to set up an effective push-and-pull strategy for animal disease control, as mentioned by Rich et al. (2011).

\section{RESULTS}

The main contribution of this paper is an improved knowledge on how to implement a push-and-pull strategy in the poultry value chain; knowledge that can be used to design an effective strategy to control animal disease. The research took a value chain perspective in the context of chain actors' responses to animal disease control. The work described in this paper was carried out in two goals: (i) increase knowledge on the poultry chain structure, and (ii) increase knowledge on a pushand-pull strategy to control HPAI (Figure 1). The work was highly interdisciplinary in nature. Different scientific perspectives (e.g. value chain, economic 
Table 1. Methods, and respondents for each perspective, and research objective of the study

\begin{tabular}{|c|c|c|c|}
\hline Perspectives & Objectives & Methods & Respondents \\
\hline \multirow[t]{2}{*}{ Value Chain } & $\begin{array}{l}\text { the complexity of poultry } \\
\text { value chain structures and } \\
\text { their influence on HPAI } \\
\text { control in Western Java }\end{array}$ & $\begin{array}{l}\text { - Value Chain Analysis } \\
\text { - Governance Structure } \\
\text { - Economic performance } \\
\text { - HPAI Risk factors }\end{array}$ & $\begin{array}{l}\text { - } 4 \text { Integrated companies } \\
\text { - } 1 \text { Slaughter association } \\
\text { - } 1 \text { Integrated Slaughter house } \\
\text { - } 3 \text { Semi-automated slaughterhouse } \\
\text { - } 4 \text { slaughter point/wet market } \\
\text { - } 2 \text { farmer associations (GOPAN, PINSAR) } \\
\text { - } 1 \text { poultry farm, } \\
\text { - } 1 \text { collecting farm, } \\
\text { - } 2 \text { specialty store } \\
\text { - } 2 \text { representatives of the banking sectors, } \\
\text { - } 4 \text { government officials, } \\
\text { - } 1 \text { representative of traders } \\
\text { - } 1 \text { representative of a traditional private } \\
\text { slaughter point associations } \\
\text { - } 1 \text { representative of Federation of the } \\
\text { Indonesian Poultry Society (FMPI). } \\
\text { - } 1 \text { representative of academia } \\
\text { - } 2 \text { representative of consultants }\end{array}$ \\
\hline & $\begin{array}{l}\text { the probability of HPAI } \\
\text { introduction and transmission }\end{array}$ & $\begin{array}{l}\text { - Expertise-based estimation } \\
\text { - Qualitative Assessment }\end{array}$ & $\begin{array}{l}\text { - } 47 \text { experts with knowledge: } \\
\text { 1) veterinary epidemiology, } \\
\text { 2) the poultry value chain in Western Java } \\
\text { 3) HPAI }\end{array}$ \\
\hline $\begin{array}{l}\text { Farms } \\
\text { (Push) }\end{array}$ & $\begin{array}{l}\text { micro governance of the } \\
\text { farms and other factors } \\
\text { influence biosecurity } \\
\text { procedures on broiler farms }\end{array}$ & $\begin{array}{l}\text { - Biosecurity control score } \\
\text { - Farm infrastructure for } \\
\text { biosecurity }\end{array}$ & $\begin{array}{l}406 \text { farms in four districts in the West Java } \\
\text { province: Ciamis, Tasikmalaya, Subang } \\
\text { and Sukabumi, }\end{array}$ \\
\hline \multirow[t]{2}{*}{$\begin{array}{l}\text { Consumers } \\
\text { (Pull) }\end{array}$} & $\begin{array}{l}\text { the factors that influence } \\
\text { the consumers' choice of } \\
\text { poultry market channels and } \\
\text { consumers' demand after the } \\
\text { HPAI outbreak }\end{array}$ & $\begin{array}{l}\text { - The choice of market } \\
\text { channel framework } \\
\text { - Multivariate logistic } \\
\text { regression }\end{array}$ & - 1,096 consumers in the Greater Jakarta \\
\hline & $\begin{array}{l}\text { evaluate consumers' } \\
\text { preferences and willingness } \\
\text { to pay for poultry meat } \\
\text { attributes }\end{array}$ & $\begin{array}{l}\text { - Utility theory } \\
\text { - Discrete Choice Experiment } \\
\text { - Willingness to pay }\end{array}$ & - 400 consumers in the Greater Jakarta \\
\hline
\end{tabular}

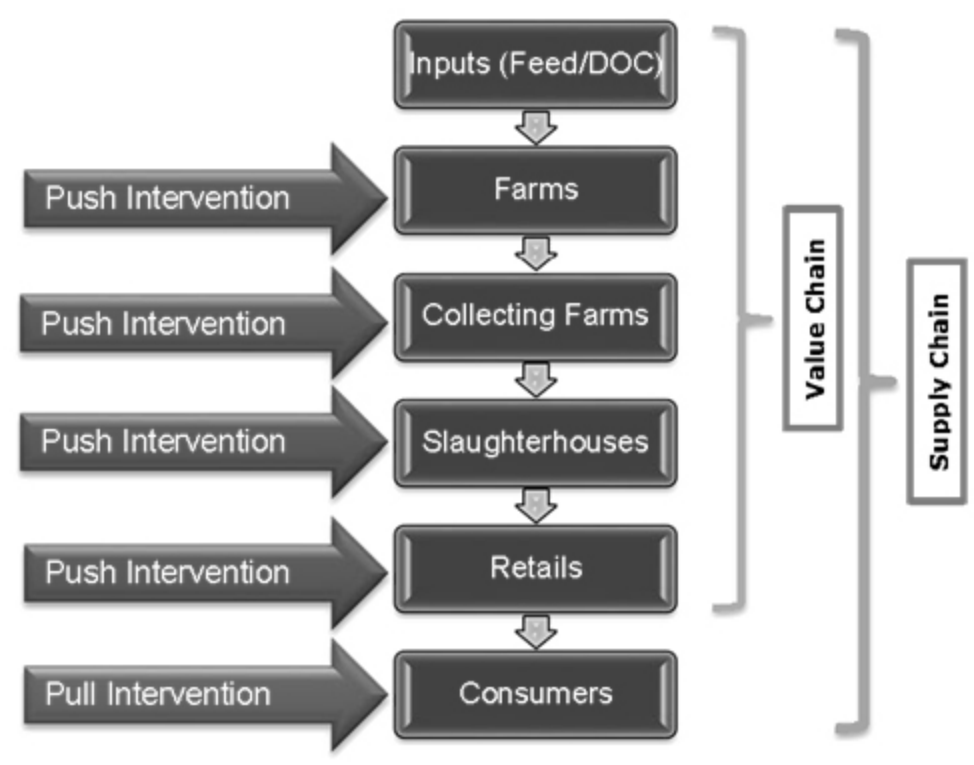

Figure 1. Push and pull intervention in the value chain and supply chain of poultry industry 
performance, epidemiology, biosecurity and consumer behavior) were linked to create a knowledge framework for improved HPAI control.

\section{The Knowledge on The Poultry Chain Structure}

The structure of the Western Java poultry production chain is very complex. We disentangled the structure by looking at the value chain as well as the consumers' perspective. We mapped the complexity of the value chain and complemented this map with insight of the value chain governance. The value chain analysis was based on a number of intensive workshops. Earlier published value chain analyses only looked at the poultry product flow (McLeod et al. 2009, Sudarman et al. 2010). The combination of a map of the structure of the poultry value chain with insight into chain governance as presented in this paper, provides a clear overview of the human interactions within the value chain and their expected response to HPAI outbreaks. Our findings show that the governance within the poultry value chain is an important factor driving interaction between actors and their response to HPAI risk. The value chain analysis was the base for further analyses linking the poultry value chain with the epidemiology of HPAI. We analyzed the two main aspects of the epidemiology of HPAI: introduction of HPAI into a poultry production chain and transmission of HPAI between actors within a poultry production chain. To the best of our knowledge, this is the first analysis of its kind. We were not able to find any literature linking the epidemiology of a contagious notifiable disease to governance of an animal production chain. Regarding HPAI, many studies (e.g. de Glanville et al. (2010), Idris et al. (2015)) on HPAI epidemiology focus on contact structure but do not take governance into account.

We identified four poultry chains and grouped them based on two marketing channels: the modern and the traditional marketing channel. The four poultry chains were defined based on slaughtering activities. Slaughtering in the modern channel is performed in slaughterhouses, while in the traditional channel it is performed at slaughter points. Therefore, we named the chains according to slaughterhouse/point characteristics. The results demonstrate the existence of four different poultry value chains in Western Java: the integrator chain, the semi-automated slaughterhouse chain, the controlled slaughter point chain and the private slaughter point chain (Indrawan et al. 2018a). Each value chain operates under a different chain governance with coordination carried out at different levels and through different mechanisms. The integrator chain was the most coordinated chain, while the private slaughter point chain was the least coordinated. Each of the chains had a distinct main supplier based on FAO farm type biosecurity classification (e.g. sector 1 farms served the integrator chain). Therefore, the chain governance is affecting the level of biosecurity on farms and in chains. Our results showed that chain governance is also having an effect on the economic consequences of HPAI incidents (Indrawan et al. 2018a), confirming findings of previous research (Van Kerkhove et al. 2009, Van Steenwinkel et al. 2011, Yupiana et al. 2010). The integrator chain, the most coordinated chain, suffers the most severe economic consequences of HPAI outbreaks, compared to the other chains. These economic consequences explain why the integrator chain has the highest level of biosecurity.

Although the four defined value chains appear to operate in isolation, we found that the less coordinated chains heavily interlink between each other in the farming areas and the live birds markets. Typically, these are the two chains working with slaughter points. However, the semi-automated slaughterhouse chain also interacts with the slaughter point chains. These interlinkages between actors across different poultry value chains do contribute to the overall risks of transmission over the Western Java poultry sector. For example, while improved biosecurity in Indonesia, combined with a test-and-cull control policy, is still the government's main strategy to control HPAI H5N1 (Azhar et al. 2010, Dolberg et al. 2009, Ilham \& Iqbal, 2011, Loth et al. 2011, Swayne \& Suarez, 2000), our results indicate that the incentive mechanisms present in most of the poultry value chains encourage a low level of biosecurity on poultry farms. Therefore, the existing chain governance is a constraint in managing HPAI risks. We identified four main constraints related to the role of chain governance in the poultry structure: the existence of a sick poultry market, the role of sector 2 farming in HPAI spread, the influence of traders, and biosecurity practices varying across farm business types.

The chain governance in the two poultry value chains in the traditional channel allow the existence of a market for sick poultry. It is an important reason for the higher probability of HPAI introduction and transmission for the two chains within this channel, and plays an important role in financial risk mitigation for the actors within those chains. This is associated with the incentive 
mechanism and penalties that may be imposed (Gramig et al. 2009, Williamson, 2002). Selling chickens affected by HPAI offers a higher financial reward than the government compensation for culling. Therefore, any poultry older than 20 days with clinical signs of disease will immediately be sold to this market. This discovery leads to the conclusion that the sick poultry market is an important reason for the endemicity of HPAI, because the test-and-cull mechanism is not applied adequately. The sick poultry market is not only accessed by sector 3 and 4 farms, it is also of interest for sector 2 farms. Although sector 2 farms operate in the modern channel, they were found to be influenced by incentives from the sick poultry market as well. For sector 2 farms, the sick poultry market became a financial mitigation in the event of an animal disease outbreak. This does have an impact on their biosecurity and the increase of risk of HPAI introduction (Paul et al. 2012, Van den Berg, 2009). Besides leading to the ineffectiveness of test-and-cull control measures, the transport of sick chickens increases the risk of transmission of HPAI. The existence of markets for sick chickens adds to the complex situation of live birds markets, already known to be an important source of transmission of HPAI (Indrawan et al. 2018a, Paul et al. 2011, Van den Berg, 2009).

The main actor driving the sick poultry market is the group of traders (Indrawan et al. 2018a). The traders govern the controlled slaughter point chain and the private slaughter point chain and are therefore important actors in the control of HPAI. Traders established their influence and their critical intermediary role in financing transactions between farmers and poultry collectors, acting as brokers matching farmers and collectors without being physically involved.

We found that chain governance plays a role in the application of biosecurity at the farm level and analyzed the related impact on the probability of HPAI introduction and transmission. The level of biosecurity on individual Indonesian poultry farms, important for reducing the risk of introduction of contagious diseases on a farm, has been described as low (de Glanville et al. 2010, Indriani et al. 2010, McLeod et al. 2009). Results from this research support that finding. In addition, the level of adoption of biosecurity, both in terms of implemented practices as in available infrastructure, was found to be low at the industrial-sized farms as well (sector 1 and 2 farms), whereas it was previously suggested that biosecurity on those farms was higher. The biosecurity practices at the farm level did not only vary between farm types (sector 1 to sector 4), but especially between farm business types. Farm sectors under a company business related to the integrator chain were found to perform slightly better than other farm business types. The different incentives applied within these business types were the cause of the variation (Basuno et al. 2010, Gerdoçi et al. 2018, Wacker et al. 2016). There was an association between the level of biosecurity practices at a farm and the economic consequences of HPAI incidents (Van Kerkhove et al. 2009, Van Steenwinkel et al. 2011, Yupiana et al. 2010) . The farms that, without any government intervention, would face the most severe economic consequences of an outbreak had the highest level of biosecurity. The farm business models are closely related to the chain governance. This means that chain governance also plays a role in the level of biosecurity at the farm level.

In order to complete the value chain approach towards HPAI control, we also analyzed the Western Java poultry chain structure from the consumers' perspective. The modern channel is considered to sell poultry meat of better quality, with a higher level of food safety, than the traditional channel. In the traditional channel, live bird markets are a source of HPAI transmission, chickens are slaughtered at slaughter points and sold at wet markets, which both are less hygienic. By using the adapted approach of Spiggle and Sewall (1987) and Heider and Moeller (2012), we studied the determinants influencing the consumers to buy from each market channel and found several differences (Indrawan et al. 2018b) . Consumers purchasing poultry meat from the modern channel were influenced by the price/quality relationship (also concluded by $\mathrm{Yu}$ et al. 2011), the safety feature, and the level of consumer trust. On the other hand, consumers purchasing poultry meat from the traditional channel were influenced by freshness (also concluded by Chamhuri et al. (2015), Daryanto et al. (2014), Sujiwo et al. (2018)), place of residence (inside/outside Jakarta), and the amount of poultry meat per purchase. The findings indicate that the two marketing channels, the modern and traditional channel, serve different consumers with a different perception of poultry meat quality and food safety. 
To elaborate on these findings, we employed a discrete choice experiment to explain consumers' preferences regarding features on poultry meat quality and food safety. We studied the Western Java consumers' choice of attributes of poultry meat and their willingness to pay (WTP) for these attributes. The findings confirmed that freshness as a meat quality attribute is more important than food safety attributes (Goldman and Hino, 2005, Goldman et al. 1999, Verbeke and Viaene, 1999) , i.e. Western Java poultry consumers use freshness as a synonym for quality (Chamhuri et al. 2015). As a consequence, consumers' willingness to pay for freshness was found to be higher than for other poultry attributes (food safety certification and product information label), in both the traditional and modern channels. A product information label was perceived as positive: consumers preferred poultry meat with a product information label over poultry meat without a product information label (finding supported by work of Stranieri and Banterle, 2015; Verbeke and Ward, 2006). Furthermore, the consumers had a higher preference for government certification than for private certification (Wahida et al. 2013).

\section{The Knowledge on The Push-and-pull Strategy to Control HPAI}

In order to control HPAI in Western Java, it is important to pay attention to the interrelations between the actors in the chain. These interactions affect the incentive mechanisms for the chain actors to improve production methods and to influence consumers (Kaplinsky and Morris, 2001). Good insight in these incentive mechanisms are the cornerstone to effective control measures for HPAI. In general, two approaches can be taken to improve the quality of production. The first is to push producers to improve production and the second is to have consumers pulling the market towards better products. Control of HPAI is a quality aspect of poultry production, especially because of the link with food safety. When a government wants to improve the control of HPAI, it can do so within the current structure of the value chain. A government intervention will be more effective, if it is tailored to the structure of the value chain and the interactions between actors within the supply chain. When disease control is hampered too much by an existing poultry chain structure, governments may consider to restructure it. In the case of the Western Java poultry value chain, a restructured value chain would start with a shift of production and sales of poultry from the traditional channel to the modern channel. Results of the value chain analysis carried out in this paper, linked to the epidemiology of HPAI, do support the idea that a restructured poultry value chain in Western Java would improve the control of HPAI. The consumer can play an important role in this shift, since a shift in purchase behavior (from the traditional to the modern market) will lead to a shift in production (a pull strategy). The results show, however, that it is not easy to motivate consumers to shift from the traditional to the modern market. The diversity found in governance typology implies that there is no "one-size-fits-all" strategy for HPAI control (Indrawan et al. 2018a). Therefore, it may be recommended to combine the push and pull strategies. The push strategy, i.e. creating incentives for actors in the poultry value chain to carry out measures reducing the risk of introduction and transmission of HPAI, should be combined with measures to support consumers to pull the production of poultry towards the modern market. This research, together with other knowledge, provides some key insights in the incentive mechanisms for chain actors, including consumers, which can be used to design an effective push-and-pull strategy (Chitchumnong and Horan, 2018, Gramig et al. 2009, Rich and Perry, 2011).

In order to control HPAI, a push strategy seems to be a quick way to improve the quality of production in the poultry value chain. Pushing for improved biosecurity, for instance by a test-and-cull approach in case of outbreaks on a farm, or for improved hygienic measures, seems relatively easy. However, the previous government efforts to improve biosecurity and to control live bird markets failed due to limited participation from chain actors (Azhar et al. 2010, Dolberg et al. 2009, Ilham and Iqbal, 2011, Loth et al. 2011, Swayne \& Suarez, 2000). Apparently, governmental efforts were not adapted to the existing chain governance and incentive mechanisms in the Western Java poultry sector. In the existing poultry structure, incentives to trade sick chickens in a sick poultry market were facilitated by traders not even physically involved in the trade of poultry (Gramig and Horan, 2011, Gramig et al. 2009). So, the results of any effort to increase the level of biosecurity or to implement other measures in the value chain depend on the influence of incentive mechanisms, including the economic consequences of HPAI incidents under the current chain governance (Van Kerkhove et al. 2009, Van Steenwinkel et al. 
2011, Yupiana et al. 2010). Therefore, the design and implementation of a push strategy needs to take the role of current chain governance in the poultry structure into account. This implies that the role of the chain leader should be taken into account when the government considers any intervention. A push strategy providing sufficient incentives for all critical chain actors will be able to drive the interaction between actors to participate in the control measures, and will therefore be much more effective.

In the current situation, there are little or no incentives for all the actors (including the traders) to improve their behavior regarding HPAI. Moreover, a sick poultry market is in place, creating an opposite incentive in case of an outbreak. Therefore, HPAI is not expected to be controlled, especially since we found that traders, who have large market power and are chain leaders in two of the four identified value chains, were never involved in HPAI control measures. Any control measure aimed to reduce the number of chickens being traded will reduce the profits of traders. When a test-and-cull measure is combined with a compensation for the farmer, the trader will still have some revenues forgone and will not willingly collaborate. The removal of the sick poultry market, while creating much better incentives for farmers to comply to a test-and-cull measure, would reduce the traders' profitability even more. When not collaborating with the trader, there will be no incentives at all for them to participate in HPAI control measures, rather they will use their oligopolistic power to avoid losing any market share. Therefore, traders will need to be included, with clear economic or other incentives to cooperate (Gramig and Horan, 2011, Gramig et al. 2009). A similar situation regarding the sick poultry market applies to the interaction of sector 2 farms in other poultry value chains.

In order to push for improved biosecurity at the farm level, the government needs to provide incentives for farmers in the controlled slaughter point chain and the private slaughter point chain. Interestingly, we found that a formal registration as a poultry farm business was associated with a higher level of biosecurity investment and implementation. Apparently, governmental incentives were created through agricultural extension services that deliver information and/or laboratory services to farmers after formal registration did provide an incentive for the farms. The incentives should take the farms' business type into account. We expect from our results that taking poultry farm business types into account in the incentive will influence the adoption of biosecurity practices infrastructure (Basuno et al. 2010, Gerdoçi et al. 2018, Wacker et al. 2016). That way, adjusting new incentive mechanisms according to the farm business type will support the government's effort to control HPAI (Barnes et al. 2015, Gramig \& Horan, 2011).

Besides pushing measures to control HPAI in the poultry value chain, the government can also motivate consumers to play a role in changing the poultry value chain. One way to control HPAI is to pull the market channels towards a specific chain structure. Based on the consumer studies in this paper, additional insight can be provided in consumer behavior regarding poultry meat quality and food safety in relation to the existing market channels. Although a lot of research into consumers' behavior exists regarding food safety (e.g. Röhr et al. (2005) and Grunert (2005)), so far only one paper dealt with the response of consumers to the HPAI outbreak (Muladno and Thieme, 2009).

Our research shows that around 80 percent of consumers purchase poultry meat in the traditional channel. Consumers are mainly influenced by freshness as the key determinant factor for purchase. Moreover, the role of freshness as a meat quality attribute is more important than food safety attributes. The Western Java poultry consumers see warm chicken (i.e., freshly slaughtered chicken) as a sign of freshness, perceived as a synonym for quality (Chamhuri et al. 2015). Per definition, the freshness of warm chicken is higher than of cooled or frozen chicken. Thus, consumers' willingness to pay for freshness was found to be higher than for other food attributes. Therefore, without changing the perception of freshness, it will be difficult to change the consumers' behavior and influence their choice for market channel.

Consumer perceived freshness is a key driver to purchase poultry on the traditional market (Chamhuri et al. 2015, Daryanto et al. 2014, Indrawan et al. 2018b), and freshness was defined related to slaughtering on the spot or the night before sales (Indrawan et al. 2018b, Zhang, 2003). At the same time, this practice is less hygienic and carries greater risk of contamination and growth of pathogens. Moreover, chickens from the sick poultry market, providing less safe poultry meat, are also sold through this channel. Because of the clear trade-offs between freshness and food safety, a redefinition of freshness is required in order to promote 
safer poultry meat. So, the success of a pull strategy relies on the consumers' perception and judgment of the products (Chamhuri and Batt, 2015), and on their trust in food chain actors to provide safety in their food product in the market channels (Arnot et al. 2016, de Jonge et al. 2007, de Jonge et al. 2008, Drescher et al. 2012), rather than on objective criteria.

In order to be able to pull changes in the value chain, the preference of consumers' needs to be changed or overcome. The preference of consumers for warm chicken can be reduced by means of a pricing mechanism: the Western Java consumers were found to associate price with quality (Indrawan et al. 2018b) . The price difference in the modern market should be large enough to overcome the consumers' willingness to accept meat that is perceived as less fresh. Price level differences can be created via subsidy or tax mechanisms. Another option to change the behavior of consumers is to promote food safety and/or a new way of defining freshness. Such an effort should change the consumers' preference towards poultry meat quality and food safety. Then, the changing consumer demand of will pull an upgrade or an improvement of the production chain.

\section{Managerial Implications}

The current approach regarding HPAI control in Indonesia is limited to farms and live bird markets. It is aimed at preventing the spread of HPAI without looking at the interaction between actors in the value chain. As mentioned above, this approach is not effective in controlling HPAI sufficiently. When discussing policy making options, we should take into account that Indonesia is considered to be a low-resource country. For this reason, designing an intervention strategy for controlling HPAI in Indonesia is a difficult task and should be performed in such a way as to maximize the reduction HPAI, given the available budget, rather than aiming at complete eradication of HPAI.

Our results revealed that the main task to be undertaken by the government is the removal of the sick poultry market. The sick poultry market hampers effective control of HPAI in multiple ways. The first is that is brings an incentive for flawed behavior in case of an HPAI outbreak, by providing a market for chickens affected by HPAI. Therefore, test-and-cull measures are not and will not be effective, unless the payment for farmers will exceed the payment on the sick poultry market, making test and cull very expensive. The existence of the sick poultry market mitigates the financial consequences of an HPAI outbreak for farmers. Animals infected with HPAI still have value and economic incentives for improved biosecurity are therefore low. During transport, the probability of transmission of HPAI by sick chickens will be much higher. So the sick poultry market not only has a negative effect on biosecurity and a proper reaction during an outbreak, it even increases the HPAI problem.

When designing and performing measures to remove the sick poultry market, the government should involve the chain actors. It is preferable if chain actors, especially leaders (i.e., traders) join the government's efforts voluntarily, eventually encouraged by incentive mechanisms. A part of the available budget might be dedicated to incentives. The main attention of pushing a removal of the sick poultry market should be aimed at the traditional channel. The strategy should engage the traders (who were left out from previous control programs) by paying attention to their incentives to preserve the sick poultry market. A potential direction to provide the traders with an incentive to join efforts to remove the sick poultry market is to upgrade their role from informal to formal commercial agents, similar to financial institutions or collecting farms (Indrawan et al. 2018a). As formal commercial agents, the traders will become more involved to stimulate efficient and effective poultry meat production. The coordination between the traders and farmers, collecting farms, and transporters is expected to change from on-the-spot transactions to contractual, long-term agreements, thus improving coordination in the controlled slaughter point chain as well as in the private slaughter point chain. A pull approach towards a removal of the sick poultry market might take the form of an advertisement campaign, making consumers aware that a part of the poultry they buy is sick.

As described before, all Western Java poultry farms could improve their biosecurity considerably. Aremoval of the sick poultry market may modify the incentives for biosecurity improvement, but besides that, additional initiatives should be taken to push poultry farmers (including sector 1 farms) towards improved biosecurity. As proposed in the previous paragraph, improving chain coordination in the slaughter point chain and the private slaughter point chain also helps to bring incentives to poultry farmers for biosecurity improvement. Generally, when looking at incentives for 
farmers for biosecurity improvement, the farm business type should be taken into account. Moreover, proper cost-benefit analyses of improved biosecurity need to be made. A positive aspect of biosecurity is that it does not only reduce the risk of introduction and transmission of HPAI, but also of other, contagious, poultry diseases. So, the benefits of improved biosecurity are bigger than just a reduction in the damage of HPAI. A final issue regarding measures to push the production into a specific direction is the enforcement of regulations. When implementing novel regulations, they should be designed in such a way that they are easily enforced. When moving beyond voluntary changes in behavior, regulation enforcement is crucial.

A pull strategy, as the other possible direction of government intervention, will focus on consumers. It should create incentives to shift the consumers away from buying poultry meat in the traditional channel. A classical method to move consumers in a preferred direction is the adoption of economic incentives. By differentiating taxes and/or subsidies between the two channels, consumers' preferences may shift towards another channel. Another method to change consumers' preferences is to run campaigns, such as education and advertisement of healthy poultry meat. Changing taxes and/or subsidies, the government influences the price/ quality relationship for poultry meat. For instance, by subsidizing the modern channel, the consumers may buy more poultry meat from this channel. On the other hand, by additional or increased taxes in the traditional channel, the consumers may buy less in this channel. In order to do so, a proper tax or subsidy system should be implemented and, for subsidies to be effective, the market should function properly. If a tax or a subsidy has no visible effect on the consumer price, it will not be effective.

Financial incentives may be combined with health campaigns to change the consumers' preference towards the modern market. With what we have learned in our work, we now know that such campaigns should be aimed at reducing the trade-off between food safety and freshness, meaning that the government should either communicate a redefinition of freshness, or the importance of safe chicken, or both. In order for the level of food safety to be trustworthy, campaigns should be combined with food safety certification. By supporting the promotion of freshness and food safety features of poultry meat at the modern channel with financial incentives, Western Java consumers might very well start to prefer the modern channel, increasing the probability of pulling the poultry supply chain to a safer production. As a side note, we expect that a pull strategy is implemented for the long run, as it will not be effective in the short run. To make progress in the short run, the focus should be on the push strategy.

Because of the cost involved with the above measures, the evaluation of the cost-effectiveness of single or combinations of measures can be linked to the available (long term) budgets, so that the most cost-effective measure can be implemented. Distribution of costs and benefits over actors in the value chain (including the government) should be taken into account.

\section{CONCLUSIONS AND RECOMMENDATIONS}

\section{Conclusions}

First, poultry production in Western Java is organized in a highly complex structure. Four different value chains can be distinguished: the integrator chain, the semiautomated slaughter chain, the controlled slaughter point chain, and the private slaughter point chain. This complex structure is responsible for the existence of a market for sick poultry that has a very negative influence on HPAI control. Traders need to be involved in the design and implementation of HPAI control measures, since they are the informal chain leaders in the controlled slaughter point and the private slaughter point chains. A combination of a value chain analysis with expertisebased estimates for HPAI introduction and transmission did identify critical actors in the epidemiology of HPAI. The method can easily be applied to study the structure of endemic contagious disease problems in developing countries having inadequate resources for extensive epidemiological research. Second, as we found that BCS and FIB were determined by the farm business types, limited biosecurity practices and infrastructure were demonstrated for all farm business types. Traffic control practices and facilities were the lowest biosecurity performance. A makloon contract farm was found as the lowest performance of biosecurity practices and facilities than other business types.

Third, the main reason for consumers in Western Java to have a preference for the less safe, wet poultry markets, is their perception of freshness. Our study revealed that the main task to be undertaken by the government is the removal of the sick poultry market. The main attention 
of pushing a removal of the sick poultry market should be aimed at the traditional channel. The strategy should engage the traders (who were left out from previous control programs) by paying attention to their incentives to preserve the sick poultry market. A final issue regarding measures to push the production into a specific direction is the enforcement of regulations. When implementing novel regulations, they should be designed in such a way that they are easily enforced. When moving beyond voluntary changes in behavior, regulation enforcement is crucial.

\section{Recommendations}

A pull strategy, as the other possible direction of government intervention, will focus on consumers. A pull approach towards a removal of the sick poultry market might take the form of an advertisement campaign, making consumers aware that a part of the poultry they buy is sick. It should create incentives to shift the consumers away from buying poultry meat in the traditional channel. A classical method to move consumers in a preferred direction is the adoption of economic incentives. As a side note, we expect that a pull strategy is implemented for the long run, as it will not be effective in the short run. To make progress in the short run, the focus should be on the push strategy.

In our work, we have generated an extensive body of knowledge that can is valuable for the design of future control measures for HPAI in Indonesia. However, some aspects remain unclear. We have mainly worked towards a better understanding of the poultry chain structure and were able to make conclusions on general incentive mechanisms. However, we did not study specific push or pull incentives nor how these incentives might affect the actors' motivation to change their behavior. For instance, we were only able to identify generic incentives for traders to become commercial agents, or incentives for farmers to implement better biosecurity measures. We did not study any specific measures. Given the expected effectiveness (also in time), future research should focus on the implementation of specific push strategies by the government, rather than on pull strategies.

First, it is essential to help plan, implement and evaluate incentive mechanisms for the chain actors in the poultry chain structure. In a first step, based on utility theory, the economic impact of proposed measures on the involved actors should be studied, exploring the relation between chain actors, their transaction costs, and the costs of their efforts to control HPAI, and relating that to the benefits of a reduced risk of HPAI as well as of other contagious diseases. Simulation modeling is a good basis for utility-driven cost-benefit evaluation. For instance, the economic effects of the removal of the sick poultry market should be evaluated for all actors involved. In a next step, the economic effects of a proposed measure should be studied in combination with other (tangible and intangible) factors that motivate actors to behave in a certain way. These studies can be based on socialpsychological theory, such as the Theory of Planned Behavior (Ajzen, 1991), which has been used in other food safety research, including Verbeke and Viaene (1999), Verbeke and Vackier (2005), Lobb et al. (2007), and Mazzocchi et al. (2008).

To understand the interaction of actors within the different value chains, and to quantify these interactions, a Principal Agent approach (Laffont and Martimort, 2009) can be taken. In this approach, the (economic) dependencies of actors within a chain can be quantified. Principal Agent Theory has been used before in the animal production domain, for instance by King et al. (2007), who developed an incentive system for food quality control for Salmonella, by Resende-Filho and Buhr (2008), who evaluated the economic value of a traceability system, and by (Yunxian et al. 2010), who studied retailers' order contracts in a perishable product value chain.

In order to evaluate the overall effect of implementing incentives for the full value chain, the insights of intangible incentives for individual actors should be taken into account. An evaluation can be based on game theory (e.g., Delabouglise and Boni (2018) and Manfredi and D'Onofrio (2013)). Although there are no known examples of applying game theory in the control of animal diseases, some work on epidemiological game-theoretic models have been published for control of disease in humans, for instance to control influenza (Galvani et al. 2007). Another full value chain approach can be to combine epidemiological knowledge with behavioral knowledge in an agent-based model, as recently for Bluetongue virus in the Netherlands (Sok \& Fischer, 2018). In these modeling approaches, different types of incentive systems influencing poultry actors' decisions and consequences in the occurrence of HPAI can be simulated. The effects of incentive systems for farmers and traders can be studied separately, or in combination to find interactions between these 
systems. Simulations can also model the effect of budget constraints, highly relevant in low and middleincome countries.

\section{ACKNOWLEDGEMENTS}

The authors would like to acknowledge the SPIN3JRP-61 Project for the data support and collection. The first author was funded by an LPDP scholarship. The funder had no role in the contents of this study.

\section{REFERENCES}

Ajzen I. 1991. The theory of planned behavior. Organizational Behavior and Human Decision Processes 50: 179-211. https://doi. org/10.1016/0749-5978(91)90020-T.

Arnot C, Vizzier-Thaxton Y, Scanes CG. 2016. Values, trust and science - building trust in today's food system in an era of radical transparency. Poultry Science 95 2219-2224. https://doi.org/10.3382/ ps/pew168.

Authority EFS. 2006. Statement on migratory birds and their possible role in the spread of highly pathogenic avian influenza by the Scientific Panel on Animal Health an Welfare (AHAW). EFSA Journal 4, 357a. https://doi.org/10.2903/j. efsa.2006.357.

Barnes AP et al. 2015. The effect of animal health compensation on 'positive' behaviours towards exotic disease reporting and implementing biosecurity: A review, a synthesis and a research agenda. Preventive Veterinary Medicine 122: 42-52. https://doi.org/10.1016/j. prevetmed.2015.09.003.

Basuno E, Yusdja Y, Ilham N. 2010. Socio-economic Impacts of Avian Influenza Outbreaks on Smallscale Producers in Indonesia. Transboundary and Emerging Diseases 57: 7-10. https://doi. org/10.1111/j.1865-1682.2010.01121.x.

Chamhuri N, Batt PJ. 2015. Consumer perceptions of food quality in Malaysia. British Food Journal 117:1168-1187. https://doi.org/10.1108/BFJ-082013-0235.

Chamhuri N, Kusumawaty Y, Batt PJ. 2015. Consumers' purchasing behaviour for fresh meat from modern retail stores and traditional markets in Malaysia and Indonesia. Islamic Perspectives on Marketing and Consumer Behavior: Planning, Implementation, and Control. IGI Global.
Chitchumnong P, Horan RD. 2018. Managing Disease Risks from Trade: Strategic Behavior with Many Choices and Price Effects. EcoHealth 1-15. https://doi.org/10.1007/s10393-018-1329-2.

Costard S, Fournié G, Pfeiffer DU. 2014. Using Risk Assessment as Part of a Systems Approach to the Control and Prevention of HPAIV H5N1. EcoHealth 11: 36-43. https://doi.org/10.1007/ s10393-014-0907-1.

Daryanto A et al. 2014. Socio-economic analysis of the slaughtering systems in the poultry meat sector in Greater Jakarta Area.

de Glanville et al. 2010. A quantitative risk assessment for the onward transmission of highly pathogenic avian influenza $\mathrm{H} 5 \mathrm{~N} 1$ from an infected small-scale broiler farm in Bogor, West Java, Indonesia.

de Jonge $\mathrm{J}$ et al. 2007. Understanding consumer confidence in the safety of food: Its twodimensional structure and determinants. Risk Analysis 27: 729-740. https://doi.org/10.1111/ j.1539-6924.2007.00917.x.

de Jonge et al. 2008. How trust in institutions and organizations builds general consumerconfidence in the safety of food: A decomposition of effects. Appetite 51: 311-317. https://doi.org/10.1016/j. appet.2008.03.008.

Delabouglise A, Boni MF. 2018. Game theory of vaccination and depopulation for managing avian influenza on poultry farms. bioRxiv 348813. https://doi.org/10.1101/348813.

Dijkhuizen AA, Huirne RBM, Jalvingh AW. 1995. Economic analysis of animal diseases and their control. Preventive Veterinary Medicine 25:135-149.https://doi.org/10.1016/01675877(95)00535-8.

Drescher LS, de Jonge J, Goddard E, Herzfeld T. 2012. Consumer's stated trust in the food industry and meat purchases. Agriculture and Human Values 29: 507-517. https://doi.org/10.1007/s10460012-9375-9.

[FAO] Food Agriculture Organization of the United Nations. 2011. Approaches to controlling, preventing and eliminating $\mathrm{H} 5 \mathrm{~N} 1$ highly pathogenic avian influenza in endemic countries. FAO.

Galvani AP, Reluga TC, Chapman GB. 2007. Longstanding influenza vaccination policy is in accord with individual self-interest but not with the utilitarian optimum. Proceedings of the National Academy of Sciences 104: 5692-5697. https:// 
doi.org/10.1073/pnas.0606774104.

Gerdoçi B, Bortoluzzi G, Dibra S. 2018. Business model design and firm performance: Evidence of interactive effects from a developing economy. European Journal of Innovation Management 21: 315-333. https://doi.org/10.1108/EJIM-022017-0012.

Goldman A, Hino H. 2005. Supermarkets vs. traditional retail stores: diagnosing the barriers to supermarkets' market share growth in an ethnic minority community. Journal of Retailing and Consumer Services 12: 273-284. https://doi. org/10.1016/j.jretconser.2004.10.002.

Goldman A, Krider R , Ramaswami S. 1999. The persistent competitive advantage of traditional food retailers in Asia: wet markets' continued dominance in Hong Kong. Journal of Macromarketing 19: 126-139. https://doi. org/10.1177/0276146799192004.

Gramig BM, Horan RD. 2011. Jointly determined livestock disease dynamics and decentralised economic behaviour. Australian Journal of Agricultural and Resource Economics 55: 393-410.https://doi.org/10.1111/j.14678489.2011.00543.x.

Gramig BM, Horan RD, Wolf CA. 2009. Livestock disease indemnity design when moral hazard is followed by adverse selection. American Journal of Agricultural Economics 91: 627-641. https:// doi.org/10.1111/j.1467-8276.2009.01256.x.

Grunert KG. 2005. Food quality and safety: consumer perception and demand. European Review of Agricultural Economics 32: 369-391. https://doi. org/10.1093/eurrag/jbi011.

Heider R, Moeller S. 2012. Outlet patronage in onthe-go consumption: An analysis of patronage preference drivers for convenience outlets versus traditional retail outlets. Journal of Retailing and Consumer Services 19: 313-324. https://doi. org/10.1016/j.jretconser.2012.03.004.

Idris S. et al. 2015. Qualitative risk assessment of HPAI H5N1 transmission between small-scale commercial broiler chicken farms in Bogor, Indonesia. International Food Policy Research Institute (IFPRI), Washington, DC.

Indrawan D et al. 2018a. Linking supply chain governance and biosecurity in the context of HPAI control in Western Java: A value chain perspective. Frontiers in Veterinary Science 5. https://doi.org/10.3389/fvets.2018.00094

Indrawan D, Tacken G,Hogeveen H, 2018b. What drives the choice of poultry market channel and the change of purchase behavior due to highly pathogenic avian influenza outbreaks? Poultry Science 97(10): 3652-3660. https://doi. org $/ 10.3382 / \mathrm{ps} /$ pey222.

Indriani $\mathrm{R}$ et al. 2010. Environmental sampling for avian influenza virus A (H5N1) in live-bird markets, Indonesia. EmergingInfectious Diseases 16(12): 1889-1895. https://doi.org/10.3201/ eid1612.100402.

Kaplinsky, R. and M. Morris, 2001. handbook for value chain research. IDRC, Ottawa.

Kasemsuwan S et al. 2009. Qualitative risk assessment of the risk of introduction and transmission of H5N1 HPAI virus for 1-km buffer zones surrounding compartmentalised poultry farms in Thailand. The Pro-poor HPAI Risk Reduction Project Report 9.

King RP, Backus GB, Van Der Gaag MA. 2007. Incentive systems for food quality control with repeated deliveries: Salmonella control in pork production. European Review of Agricultural Economics 34: 81-104. https://doi.org/10.1093/ erae/jbl030.

Laffont JJ, Martimort D. 2009. The theory of incentives: the principal-agent model. Princeton university press. https://doi.org/10.2307/j.ctv7h0rwr.

Lancaster KJ. 1966. A new approach to consumer theory. Journal of Political Economy 74:132157. https://doi.org/10.1086/259131.

Lobb A, Mazzocchi M, Traill W. 2007. Modelling risk perception and trust in food safety information within the theory of planned behaviour. Food Quality and Preference 18: 384-395. https://doi. org/10.1016/j.foodqual.2006.04.004.

Loth $\mathrm{L}$ et al. 2011. Identifying risk factors of highly pathogenic avian influenza (H5N1 subtype) in Indonesia. Preventive Veterinary Medicine 102:50-58. https://doi.org/10.1016/j. prevetmed.2011.06.006.

Manfredi P, D'Onofrio A. 2013. Modeling the interplay between human behavior and the spread of infectious diseases. Springer Science \& Business Media.https://doi.org/10.1007/978-1-46145474-8.

Mazzocchi M et al. 2008. Food scares and trust: a European study. Journal of Agricultural Economics 59: 2-24. https://doi.org/10.1111/ j.1477-9552.2007.00142.x.

McFadden D. 2001. Economic choices. American Economic Review 91: 351-378. https://doi. 
org/10.1257/aer.91.3.351.

McLeod A et al. 2009. The use of poultry value chain mappingindevelopingHPAIcontrol programmes. World's Poultry Science Journal 65: 217-224. https://doi.org/10.1017/S0043933909000166.

Muladno M, Thieme O. 2009. Consumer Preferences for Poultry in Indonesia. GCP/RAS/228/ GERWorking paper.

Paul M et al. 2012.Understanding socio-economic determinants associated with disease spread: HPAI H5N1 in backyard poultry marketing chains, Thailand. in Proceedings of the 13th International Symposium on Veterinary Epidemiology and Economics Maastricht 2012, p. 115.

Paul M et al. 2011. Risk factors for highly pathogenic avian influenza (HPAI) H5N1 infection in backyard chicken farms, Thailand. Acta Tropica 118: 209-216.

Pramuwidyatama MG, Hogeveen H, Saatkamp. HW. 2019. A systematic evaluation of measures against Highly Pathogenic Avian Influenza (HPAI) H5N1 in West Java Province, Indonesia. Frontiers in veterinary science 6: 33 .

Resende-FilhoMA, Buhr BL. 2008. A principal-agent model for evaluating the economic value of a traceability system: A case study with injectionsite lesion control in fed cattle. American Journal of Agricultural Economics 90: 1091-1102.

Rich KM, Perry BD. 2011. The economic and poverty impacts of animal diseases in developing countries: New roles, new demands for economics and epidemiology. Preventive Veterinary Medicine 101: 133-147.

Rich KM et al. 2011. Quantifying value chain analysis in the context of livestock systems in developing countries. Food Policy 36: 214-222.

Röhr A et al. 2005. Food quality and safety - consumer perception and public health concern. Food Control 16: 649-655.

Sok J, Fischer EAJ. 2018. Farmers' heterogeneous motives, voluntaryvaccinationanddiseasespread: an agent-based model. Manuscript submitted for publication. https://doi.org/10.1093/erae/jbz041.

Spiggle S, Sewall MA. 1987. A choice sets model of retail selection. The Journal of Marketing 97111.

Stranieri S, Banterle A. 2015. Consumer interest in meat labelled attributes: Who cares? THE INTERNATIONAL FOOD AND A GRIBUSINESS MANAGEMENT REVIEW 18: 21-38.
Sudarman et al. 2010. Poultry value chains and HPAI in Indonesia: The case of Bogor. International Food Policy Research Institute (IFPRI), Washington, DC.

Sujiwo J, Kim D, Jang A. 2018. Relation among quality traits of chicken breast meat during cold storage: correlations between freshness traits and torrymeter values. Poultry science. https:// doi.org/10.3382/ps/pey138.

Sumiarto B, B Arifin. 2008. Overview on Poultry Sector and HPAI Situation for Indonesia with Special Emphasis on the Island of Java-Background Paper. Manuscript submitted for publication, Royal Veterinary College. Retrieved from http:// www. ifpri. org/publication/overview-poultrysector-and-hpai-situationindonesia-specialemphasis-island-java.

Van den Berg T. 2009. The role of the legal and illegal trade of live birds and avian products in the spread of avian influenza. Revue Scientifique et Technique 28: 93.

Van Kerkhove MD et al. 2009. Poultry movement networks in Cambodia: implications for surveillance and control of highly pathogenic avian influenza (HPAI/H5N1). Vaccine 27: 6345-6352. https://doi.org/10.1016/j. vaccine.2009.05.004.

Van Steenwinkel et al. 2011. Assessing biosecurity practices, movements and densities of poultry sites across Belgium, resulting in different farm risk-groups for infectious disease introduction and spread. Preventive Veterinary Medicine 98: 259-270. https://doi.org/10.1016/j. prevetmed.2010.12.004.

Verbeke W, Vackier I, 2005. Individual determinants of fish consumption: application of the theory of planned behaviour. Appetite 44: 67-82.

Verbeke W, Viaene J. 1999. Beliefs, attitude and behaviour towards fresh meat consumption in Belgium: empirical evidence from a consumer survey. Food Quality and Preference 10: 437445.

Verbeke W, Ward RW. 2006 Consumer interest in information cues denoting quality, traceability and origin: An application of ordered probit models to beef labels. Food Quality and Preference 17:453-467.https://doi.org/10.1016/j. foodqual.2005.05.010.

Wacker JG, Yang C, Sheu C. 2016. A transaction cost economics model for estimating performance effectiveness of relational and contractual 
governance: Theory and statistical results. International Journal of Operations \& Production Management 36: 1551-1575. https:// doi.org/10.1108/IJOPM-10-2013-0470.

Wahida, Toiba H, Umberger WJ, Minot N. 2013. Indonesian Consumers' Willingness To Pay For High-Value Agricultural Products. https://doi. org/10.17660/ActaHortic.2013.1006.50.

Williamson OE. 2002. The theory of the firm as governance structure: from choice to contract. Journal of Economic Perspectives 16: 171-195. https://doi.org/10.1257/089533002760278776.

Willyanto I, Bett B, Unger F, Randolph T. 2010. Alignment of poultry sector actors with avian influenza control in Indonesia. International Food Policy Research Institute (IFPRI), Washington, DC.

Yeung RM, Morris J. 2001. Food safety risk: Consumer perception and purchase behaviour. British Food Journal 103: 170-187. https://doi. org/10.1108/00070700110386728.
Yu UJ, Niehm LS, Russell DW. 2011. Exploring perceived channel price, quality, and value as antecedents of channel choice and usage in multichannel shopping. Journal of Marketing Channels 18: 79-102. https://doi.org/10.1080/10 46669X.2011.558826.

Yunxian H, Honglian G, Qiang F.2010.A principalagent model on retailer's order contract in perishable product supply chain. in Proceedings of the Service Systems and Service Management (ICSSSM), 2010 7th International Conference on, 2010, p. 1-4. https://doi.org/10.1109/ ICSSSM.2010.5530268.

Yupiana Y, de Vlas SJ, Adnan NM, Richardus JH, 2010. Risk factors of poultry outbreaks and human cases of H5N1 avian influenza virus infection in West Java Province, Indonesia. International Journal of Infectious Diseases 14: e800-e805. https://doi.org/10.1016/j.ijid.2010.03.014.

Zhang X. 2003. The dynamics of Chinese consumers: a case of Shanghai food consumption. Journal of International Food \& Agribusiness Marketing 14: 47-66. https://doi.org/10.1300/J047v14n01_04. 